\title{
Kultura szkoły jako moderator relacji między stresorami w pracy a zaangażowaniem w pracę nauczycieli
}

\begin{abstract}
Is school culture able to reduce the negative influence of work stressors present in teacher's work? The goal of the study presented in this paper was to test a hypothetical mechanism, according to which school's culture moderates the links between stressors and teachers' job engagement. Relying on job demands-resources theoretical model, in the investigation conducted on a large ( $\mathrm{N}=449)$ sample of teachers we found that although indeed the exposition to stress in an everyday teachers' work is negatively related to teachers' engagement, school culture serves as a buffer that moderates the relationship between stress and engagement. Among the teachers who perceived their school culture as supportive, stress did not reduce their engagement, while this effect was find in less supportive schools.
\end{abstract}

\section{Keywords:}

teachers' stress, engagement, school culture

1 Elżbieta Strutyńska, Wydział Nauk Pedagogicznych, Akademia Pedagogiki Specjalnej im. Marii Grzegorzewskiej w Warszawie, ela.strutynska@gmail.com.

2 Maciej Karwowski, Wydział Pedagogiczny, Chrześcijańska Akademia Teologiczna w Warszawie, maciek.karwowski@gmail.com. 


\section{WPROWADZENIE}

W funkcjonowanie nauczycieli wpisane jest nieustanne przeplatanie się zdarzeń i doznań sprzyjających zawodowym sukcesom (Lebuda, 2014) i stresorów, zwiększających ryzyko wypalenia zawodowego (Poraj, 2009). Te ostatnie nie tylko uznawane są za czynniki ryzyka rezygnacji z pracy (Roulston, Legette, Womack, 2005), ale i nauczycielskiej depresji i pogorszenia stanu zdrowia (Beer, Beer, 1992; Schonfeld, 1992). I choć literatura przedmiotu dostarcza argumentów na rzecz tezy, że istotna jest nie tylko obecność czynników powodujących stres, ale także posiadanie konkretnych psychologicznych charakterystyk zmniejszających lub zwiększających oddziaływanie stresorów - na przykład poczucia samoskuteczności (Betoret, 2006) lub neurotyczności (Kokkinos, 2007) - to wciąż relatywnie niewiele wiadomo na temat znaczenia czynników organizacyjnych jako możliwego bufora, niwelującego negatywne efekty stresu na funkcjonowanie nauczycieli (zob. np. Strutyńska, Gralewski, Lebuda, 2016). W tym artykule staramy się wypełnić tę lukę, sprawdzając w jakiej mierze kultura szkoły jest w stanie zredukować negatywne oddziaływanie czynników powodujących stres na zaangażowanie nauczycieli.

Wcześniejsze dociekania realizowane przede wszystkim w ramach psychologii pracy i organizacji koncentrowały się głównie na identyfikacji negatywnych czynników oddziałujących w środowisku pracy (m.in. wypalenie zawodowe, stres w pracy, dolegliwości psychofizyczne pracowników). Mniej uwagi poświęcano rozpoznaniu czynników motywacyjnych, które skutkowałyby zwiększeniem dobrostanu pracowników i stymulowały ich motywację i zaangażowanie. Lukę tę wypełnia model JD-R (Job Demands-Resources: „wymagania w pracy-zasoby”), autorstwa Bakkera, Demeroutiego i Schaufeli (2003). Dotychczasowe badania weryfikujące założenia modelu JD-R koncentrowały się na testowaniu zależności między wymaganiami w pracy/zasobami a wypaleniem zawodowym bądź zaangażowaniem w pracę, w pracach polskich uwzględniając przy tym mediacyjne i moderacyjne funkcje zasobów - m.in. relacji społecznych oraz przekonań o własnej skuteczności (por. Baka, 2013; Baka, Cieślak, 2010; Derbis, Baka, 2011; Smoktunowicz, Cieślak, Żukowska, 2013). Naszym zamiarem, realizowanym w badaniu przedstawionym w tym artykule, było przetestowanie moderacyjnego znaczenia kultury szkoły w relacji pomiędzy stresorami a zaangażowaniem nauczycieli w pracę. Wiedząc, że zaangażowanie w pracę niesie ze sobą istotne konsekwencje zarówno dla organizacji pracy szkolnej, jak i dla funkcjonowania samych nauczycieli, stoimy na stanowisku, że empiryczna weryfikacja modelu JD-R w odniesieniu do moderacyjnej funkcji kultury szkoły ma zarówno znaczenie 
teoretyczne - wzbogacając sam model - jak i praktyczne, może bowiem stanowić impuls dla opracowania dobrych praktyk w zakresie kształtowania kultury szkoły, a w konsekwencji - dobrostanu nauczycieli i powiązanych z nim wyników organizacyjnych pracy szkoły.

\section{KULTURA SZKOŁY JAKO POTENCJALNY WYMIAR OCHRONNY PRZED CZYNNIKAMI RYZYKA}

Kultura szkoły od wielu lat jest przedmiotem rozważań teoretycznych i - mniej licznych - badań empirycznych. W Polsce studia nad kulturą szkoły realizowane są przede wszystkim w nurcie jakościowym, interpretatywnym (por. Adrjan, 2001; Nalaskowski, 2002; Polak, 2007). Tymczasem za granicą badacze zarówno amerykańscy (por. Bruner, Greenlee, 2004; Olson, 2009), jak i europejscy (Maslowski, 2001) czy azjatyccy (por. Gumuseli, Eryilmaz, 2011) analizują poszczególne wymiary kultury szkoły w ramach strategii ilościowej, posiłkując się teoriami zarządzania czy organizacji i wykorzystując wystandaryzowane narzędzia zaprojektowane specjalnie na potrzeby badań kultury szkoły. W takim ilościowym podejściu badawczym osadzone są również nasze badania.

Zdarza się, że kulturę szkoły utożsamia się z klimatem szkoły, a oba pojęcia stosuje zamiennie (zob. dyskusja Karwowski, 2009, 2013). Tymczasem badacze tych zagadnień zgodnie podkreślają, że choć klimat organizacyjny i kultura są ze sobą powiązane, to nie są to kategorie tożsame (zob. Schein, 2004). Badania klimatu i kultury wynikają bowiem z różnic na poziomie ontologicznym i epistemologicznym (Glick, 1985).

Historycznie koncepcja klimatu wyrasta z psychologicznej teorii pola Lewina, co wiąże się z podejściem ilościowym, koncepcja zaś kultury zaś z antropologii, co implikuje podejście jakościowe. Jedni badacze włączają wartości, normy i przekonania organizacji w koncepcję klimatu, czyli traktują klimat identycznie z kulturą organizacyjną (np. Paluchowski, 1998), inni - dokonują rozróżnienia między klimatem i kulturą (np. Ashforth, 1985; Ekvall, 1996). Niektórzy badacze ujmują kulturę organizacyjną jako komponent klimatu (por. Kulesza, 2011), inni zaś odwrotnie - klimat organizacyjny podporządkowują szerszej koncepcji kultury, przy czym stwierdzają, że stanowi jeden z jej podstawowych elementów (James, Jones, 1974). Dla jednych to klimat jest definiowany poprzez pryzmat wspólnego postrzegania praktyk organizacyjnych i procedur wynikających z interakcji między członkami organizacji (np. Schneider, Snyder, 1975), dla innych zaś jest obiektywną właściwością organizacji (np. Forehand, von Haller, 1964). Jak łatwo 
więc zauważyć, trudno tu o konceptualne porozumienie, a opisywane w literaturze przedmiotu relacje między kulturą a klimatem organizacyjnym (m.in.: Hofstede, 2000; Schein, 2004; Sułkowski, 2008; Wudarzewski, 2012) oraz między kulturą szkoły a klimatem szkoły (m.in.: Denison, 1996; Dernowska, Tłuściak-Deliowska, 2015; Kulesza, 2011; Schoen, Teddlie, 2008; Surzykiewicz, 2000; Tłuściak-Deliowska, Dernowska, 2016; Van Houtte, Van Maele, 2011) trudno uznać za w pełni klarowne. W dalszej części tego wprowadzenia dążymy do uporządkowania i zdefiniowania tych kategorii dla celów naszych analiz empirycznych.

W literaturze przedmiotu wskazuje się na istnienie trzech kategorii definicji kultury szkoły (Schoen, Teddlie, 2008)3. Pierwsza z nich akcentuje znaczenie wartości i przekonań jednoczących wszystkich uczestników życia szkoły (Deal, Kennedy, 1982, 1983). Druga - ujmuje kulturę szkoły jako swoistą optykę postrzegania siebie i szkolnej rzeczywistości: społecznej, symbolicznej, materialnej (Hargreaves, 1994). Ostatnia kategoria odnosi się natomiast do niepisanych norm i oczekiwań wyznaczających ludzkie działania, dążenia, sposoby myślenia i wartościowania (Peterson, Deal, 2002).

Jedną z bardziej płodnych heurystycznie koncepcji kultury szkoły zaproponował Gruenert (1998), który definiuje ją jako wspólny dla członków społeczności szkolnej zbiór przekonań, wartości i zwyczajów, które odzwierciedlają, „jak w danej szkole zwykło się robić pewne rzeczy”. Tym samym, jego zdaniem, kultura jest decydującym czynnikiem stojącym za sukcesem lub porażką organizacji. Podobnie Fisher, Frey i Pumpian (2012) postrzegają kulturę szkoły jako złożony system wartości i norm postępowania, jednoczący wszystkie podmioty edukacji (dyrekcję, nauczycieli, uczniów i rodziców) i wspierający ich w budowaniu poczucia grupowej tożsamości oraz sprawczości. Ma się ona rozwijać na bazie określonej wizji szkoły i determinować powodzenie w zakresie aktywnej adaptacji do wyzwań stawianych przez przeobrażającą się rzeczywistość, w konsekwencji wpływając na jakość pracy szkoły i jakość pracy w szkole.

Kultura organizacyjna oferująca wsparcie to czynnik przekładający się na przywiązanie pracowników do organizacji ${ }^{4}$, w przypadku szkoły - nauczycieli (Balay, Ipek, 2010). Badania pokazują, że pozytywny klimat szkoły i wynikające zeń dobre interpersonalne relacje uczniów i nauczycieli są predyktorami przywiązania

3 Szeroki przegląd definicyjny kultury szkoły i sposobów jej pomiaru zawierają między innymi prace, Maslowski (2001), Polak (2007), Schoen i Teddlie (2008), Tłuściak-Deliowska, Dernowska (2018).

4 Należy zauważyć, że przywiązanie do organizacji (organizational commitent) i zaangażowanie w pracę (work engagement) ujmują zbliżone, acz odmienne konstrukty. Niemniej obydwa dotyczą funkcjonowania zawodowego pracowników (Łaguna, Mielniczuk, Żaliński, Wałachowska, 2015). 
nauczycieli do organizacji (Collie, Shapka, Perry, 2011), choć biorąc pod uwagę korelacyjny charakter badań, trudno tu oczywiście o jednoznaczne konkluzje przyczynowo-skutkowe. Nie budzi jednak wątpliwości, że nauczyciele, którzy mają lepsze relacje z uczniami, nie tylko dostrzegają ich motywację do uczenia się, ale mają też większą satysfakcję z pracy i poczucie większej skuteczności (Collie i in., 2011). W konsekwencji nauczyciele ci są bardziej przywiązani do zawodu, ponieważ doświadczają większego poczucia dobrostanu i większego poczucia skuteczności w nauczaniu niż nauczyciele mający gorsze relacje z uczniami. Inne badania pokazują, że kultura organizacyjna istotnie przekłada się na zadowolenie z pracy i przywiązanie do organizacji, przy czym kultura biurokratyczna generuje niską satysfakcję i przywiązanie, a kultura innowacji i wsparcia zdaje się budować wysokie zadowolenie i przywiązanie do organizacji (Silverthorne, 2004). Nie ma więc wątpliwości, że zarówno klimat jak i kultura szkoły - choć nie są sobie tożsame - stanowią czynniki kształtujące nauczycielskie zaangażowanie i zadowolenie z pracy.

Podsumowując powyższe rozważania, w dalszej części tego artykułu bliska nam będzie perspektywa, zgodnie z którą klimat to: „zjawisko oddające ludzką percepcję lub przekonania na temat środowiskowych atrybutów kształtujących oczekiwania na temat efektów, warunków, wymagań i interakcji ze środowiskiem [...] A więc klimat w przeciwieństwie do kultury jest uwewnętrznionym fenomenem oddającym doświadczane, środowiskowe naciski na poziomie indywidualnym lub grupowym (Hunter, Bedell, Mumford, 2007, s. 70). Kulturę szkoły zaś utożsamiać będziemy z podzielanymi na poziomie placówki normami i wartościami, silniej zakorzenionymi w jej historii (Heck, Marcoulides 1996; Peterson, Deal, 2002). Oczywiście zarówno kultura szkoły, jak i jej klimat odciskają swoje piętno na osiągnięciach szkolnych uczniów (MacNeil, Prater, Busch, 2009) i satysfakcji uczestników życia szkolnego.

\section{WYMAGANIA I ZASOBY A FUNKCJONOWANIE W WARUNKACH SZKOŁY}

Model JD-R - uznawany współcześnie za jeden z wiodących modeli stresu zawodowego - łączy w sobie dwie tradycje badawcze - job design i job stress - pozwalające wyjaśnić, jak wymagania w pracy i zasoby (osobiste i miejsca pracy) oddziałują na stres związany z pracą i motywację (Bakker, Demerouti, 2007)5.

5 Szeroki przegląd innych modeli teoretycznych źródeł stresu zawodowego zawierają prace innych polskich autorów (Baka, 2013; Ogińska-Bulik, 2006; Terelak, 2008; Widerszal-Bazyl, 2003). 
Wymagania zawodowe odnoszą się do tych fizycznych, psychologicznych, społecznych i/lub organizacyjnych aspektów pracy, które wymagają długotrwałego psychologicznego i/lub fizjologicznego wysiłku i dlatego wiążą się z kosztami fizjologicznymi i/lub psychologicznymi, jakie musi ponieść pracownik (Demerouti, Bakker, Nachreiner, Schaufeli, 2001). Takimi wymaganiami mogą być na przykład wysoka presja związana z pracą czy praca silnie angażująca afekt i emocje. Wysokie wymagania niekoniecznie muszą mieć negatywne skutki, ale mogą przekształcić się w stresory, kiedy sprostanie im wymaga dużego wysiłku od pracownika, a koszty z niego wynikające nie zostaną odpowiednio zrekompensowane (Meijman, Mulder, 1998). Z kolei kategoria zasobów pracy odnosi się do fizycznych, psychologicznych, społecznych i/lub organizacyjnych aspektów pracy, które: a) są funkcjonalne w osiąganiu celów zawodowych; b) redukują koszty psychofizjologiczne związane z wymaganiami pracy; c) stymulują osobisty rozwój i uczenie się (Bakker, 2011; Bakker, Demerouti, 2007).

Wymagania i zasoby w pracy oddziałują na funkcjonowanie pracowników poprzez dwa niezależne procesy: energetyczny i motywacyjny, które wyznaczają osiągane efekty organizacyjne. Badania pokazują, że wymagania w pracy (presja, obciążenie pracą, problemy komputerowe, wymagania emocjonalne, zmiany w zadaniach) są istotnymi predyktorami wypalenia zawodowego i problemów zdrowotnych związanych z absencją chorobową (np. Bakker, Demerouti, Schaufeli, 2003; Hakanen, Bakker i Schaufeli, 2006). Wypalenie pośredniczy między wymaganiami w pracy a zdrowiem pracowników i ich dobrym samopoczuciem, nie tylko funkcjonując jako mediator w tym procesie, ale także odpowiadając za stopniowy drenaż zasobów umysłowych pracowników. Jednocześnie w procesie motywacyjnym zasoby pracy (wsparcie społeczne, coaching przełożonego, sprzężenie zwrotne, wydajność i kontrola czasu) są zazwyczaj czynnikami pozytywnie przekładającymi się na przywiązanie do organizacji, motywacji i zaangażowanie w pracę, które z kolei są ujemnie związane z intencją odejścia z pracy (Bakker, Hakanen, Demerouti, Xanthopolou, 2007; Hakanen i in., 2006). Badania pokazują, że konflikt interpersonalny i ograniczenia organizacyjne zmniejszają poziom zaangażowania w pracę, skutkując wzrostem ryzyka wypalenia. Co jednak ciekawe, choć obciążenie pracą działa jako czynnik zwiększający poziom zaangażowania, to ostatecznie również prowadzi do wypalenia (Derbis, Baka, 2011). Tym samym efekt różnych wymagań pracy na zaangażowanie w pracę jest różny. Środowiska pracy, które oferują wiele zasobów, sprzyjają również gotowości pracowników do poświęcania się stawianym przed nimi zadaniom. Zasoby w pewnej mierze pełnią więc rolę zewnętrznej motywacji, ponieważ inicjują gotowość podjęcia wysiłku, zmniejszając wymagania w pracy i wspie- 
rając osiągnięcie celu. W naszych badaniach koncentrujemy się wyłącznie na procesie motywacyjnym modelu JD-R.

Wyniki wcześniejszych badań przekonująco pokazały, że w przypadku pracowników cechujących się wysokim poziomem zasobów, stres może nie tylko nie osłabiać ich zdrowia, lecz nawet oddziaływać jako dodatkowy czynnik stymulujący do rozwoju (Mearne, Cain, 2003; por. Schaufeli i Bakker, 2004). Przykładem takiego zasobu, który ma znaczenie dla radzenia sobie w trudnych sytuacjach, są między innymi wsparcie społeczne, klimat psychologiczny i psychospołeczny klimat dla bezpieczeństwa.

Wyniki badań nad moderującą rolą wsparcia społecznego nie są jednoznaczne (Cohen, Wills, 1985). Jak pokazuje systematyczny przegląd badań na ten temat (van der Doef, Maes, 1999), buforowy efekt wsparcia wobec wymagań w pracy potwierdzono jedynie w 2 z 5 badań nad ogólnym dobrostanem, w 2 z 6 badań nad satysfakcją z pracy oraz w 1 badaniu nad zadowoleniem z pracy. Wykazano, że postrzegane wsparcie w pracy jest moderatorem relacji „wymagania w pracy-wypalenie zawodowe” (Sargent, Terry, 2000; por. Baka, 2013; Derbis, Baka, 2011). W polskich badaniach moderujący efekt wsparcia społecznego odnotowano w przypadku relacji pomiędzy ograniczeniami organizacyjnymi a zaangażowaniem w pracę (Smoktunowicz i in., 2013) oraz w relacji między konfliktem interpersonalnym a zaangażowaniem w pracę (Baka, Cieślak, 2010).

Za istotny zasób w warunkach pracy uznawany bywa również klimat psychologiczny panujący w organizacji, który działa jako bufor w relacji między wymagania a zaangażowaniem w pracę (Bakker i in., 2007). Wykazano, że psychospołeczny klimat dla bezpieczeństwa ${ }^{6}$ działa jako czynnik chroniący pracowników przed depresją w sytuacji znaczących wymagań w pracy (Hall, Dollard, Winefield, Dormann, Bakker, 2013). Ponadto klimat dla bezpieczeństwa moderuje związek między postrzeganym ryzykiem a zadowoleniem z pracy (Nielsen, Mearns, Matthiesen, Eid, 2011): gdy pracownicy, którzy oceniają klimat bezpieczeństwa jako pozytywny, raportują wyższy poziom zadowolenia z pracy niż pracownicy negatywnie go oceniający, nawet wtedy poziom postrzeganego ryzyka jest równy (Nielsen i in., 2011). Inne badania pokazały też, że wspierający klimat dla innowacji łagodził negatywny efekt wymagań w pracy na wydajność organizacji (King, Chermont, West, Dawson, Hebl, 2007).

6 Psychospołeczny klimat dla bezpieczeństwa jest specyficznym komponentem klimatu organizacyjnego, który odnosi się do wspólnego postrzegania polityk, praktyk i procedur odzwierciedlonych w komunikowaniu pozycji organizacyjnej dotyczącej wartości zdrowia psychicznego i bezpieczeństwa pracowników w miejscu pracy. 
Wymagania w pracy wzmacniają też wpływ zasobów pracy na motywację i zaangażowanie. Wykazano, że zasoby redukują negatywny związek między złym zachowaniem uczniów a zaangażowaniem w pracę fińskich nauczycieli (Bakker i in., 2007). Zasoby pracy są ważne w motywowaniu nauczycieli, zmniejszając ryzyko ich odejścia (Schaufeli, Bakker, 2004), zwiększając zaś tendencje prospołeczne wśród nauczycieli (Bakker i in., 2004). Naturalnym jest więc oczekiwanie, że inwestycje w zasoby pracy mogą być dla szkół bardzo opłacalne.

Powody, dla których zasoby pracy mogą mieć zarówno potencjał motywacyjny, jak też działać jako bufory niwelujące negatywne skutki stresu, są zróżnicowane. Wsparcie przełożonego może łagodzić wpływ wymagań w pracy na napięcie (psychologiczne, fizyczne i behawioralne), ponieważ stawia wymagania w innej perspektywie. Uznanie i wsparcie przełożonego mogą również wspomagać nauczycieli w radzeniu sobie z wymaganiami w pracy i ułatwiać realizację zadań (Bakker, Demerouti, 2014). Z kolei klimat organizacyjny i innowacyjność mają kluczowe znaczenie dla zaangażowania w pracę, ponieważ pozwalają traktować pracę jako ciekawą i pełną wyzwań, pobudzając motywację wewnętrzną.

Badania zaangażowania w pracę wyrosły z nurtu badań nad wypaleniem zawodowym, stanowiąc jego przeciwległy biegun (Langelaan, Bakker, von Doornen, Schaufeli, 2006; Leiter, Maslach, 1999). Nowsze badania pokazują jednak, że zaangażowanie w pracę jest niezależnym konstruktem (Bakker, Schaufeli, Leiter, Taris, 2008; Schaufeli, Bakker, 2003), na który składają się trzy symptomy: wigor (związany z energią objawiającą się chęcią podjęcia wysiłku do pracy), poświęcenie się pracy (silne utożsamianie się ze swoją pracą, poczucie jej znaczenia, entuzjazmu, dumy z jej wykonywania) i pochłonięcie przez pracę (koncentrację i całkowite zainteresowanie się pracą przy niezauważaniu upływu czasu, ale z zachowaniem możliwości zaprzestania działania) (Schaufelli, Salanova, Gonzalez-Roma, Bakker, 2002).

Zaangażowanie w pracę jest silnie związane z wieloma zasobami człowieka, np. z poczuciem własnej skuteczności (Baka i Cieślak, 2010), poczuciem kontroli w pracy i wsparciem społecznym (Bakker, Demerouti, Taris, Schaufeli i Schreurs, 2003), jak również cechami pracy, m.in.: stymulującym charakterem pracy, jej różnorodnością, autonomią, możliwością identyfikacji z realizowanymi zadaniami czy możliwością współuczestnictwa w podejmowaniu decyzji (Lawler, Hall, 1970). Interakcja stresu organizacyjnego i wsparcia społecznego (Smoktunowicz i in., 2013) oraz poczucie dopasowania do pracy mierzone sześcioma obszarami pracy (relacje z przełożonymi, wartości, sprawiedliwość, wynagradzanie i docenianie, relacje ze współpracownikami, kontrola) (Chirkowska-Smolak, 2012) okazały się istotnymi predyktorami zaangażowania w pracę. 
Zgodnie z modelem JD-R, środowisko bogate w zasoby istotnie wpływa na zaangażowanie pracowników (Bakker i in., 2007). Do zasobów tych należą między innymi uznanie wsparcie społeczne, innowacyjność (Salanova i in., 2006), orientacja na skuteczność i odpowiedzialność społeczna firmy (Szabowska-Walaszczyk, Zawadzka, Wojtaś, 2011), ale i ogólniej rozumiana wspierająca kultura organizacyjna (O’Reilly, Chatman i Caldwell, 1991; por. Terelak, Jankowska, 2006).

\section{BADANIE WŁASNE}

Celem badań prezentowanych poniżej było przetestowanie hipotetycznego mechanizmu buforującego, według którego kultura szkoły może niwelować negatywne oddziaływania stresorów w pracy na nauczycielskie zaangażowanie. Ograniczyliśmy się do badań ilościowych, wykorzystując model JD-R jako teoretyczny kontekst. Na podstawie literatury przedmiotu postawiono dwie hipotezy badawcze:

H1: Stresory w pracy będą ujemnie związane z zaangażowaniem w pracę.

H2: Kultura szkoły będzie moderowała efekt stresorów w pracy na zaangażowanie w pracę.

\section{METODA}

\subsection{Osoby badane}

W badaniach uczestniczyło 449 studentów zaocznych studiów magisterskich i podyplomowych Akademii Pedagogiki Specjalnej im. Marii Grzegorzewskiej w Warszawie, którzy pracują w szkołach podstawowych i przedszkolach położonych na terenie województwa mazowieckiego. Respondenci to nauczyciele w wieku od 22 do 56 lat $(M=28,28 ; S D=6,97)$. Zdecydowaną większość badanych stanowiły kobiety ( $\mathrm{N}=443,99 \%)$. Badani legitymowali się wykształceniem wyższym.

\subsection{Narzędzia badawcze}

Zaangażowanie w pracę. Do pomiaru zaangażowania w pracę zastosowano skróconą wersję Ultrecht Work Engagement Scale (Schaufelli i in., 2002) w polskiej adaptacji Szabowskiej-Walaszczyk, Zawadzkiej i Wojtaś (2011). Krótka wersja skali składa się z 9 itemów mierzących trzy wymiary zaangażowania w pracę: wigor (np. „W pracy czuję, że rozpiera mnie energia”), poświęcenie się pracy (zwane 
też oddaniem pracy, np. „Jestem oddany swojej pracy”) oraz pochłonięcie przez pracę (zwane też zaabsorbowaniem pracą, np. „Zapominam się, kiedy pracuję”). Badani ustosunkowują się do stwierdzeń dotyczących samopoczucia w pracy za pomocą 7 stopniowej skali odpowiedzi (od $0=$ nigdy, do $6=$ zawsze). Rzetelność całej skali była wysoka $(\alpha=0,94)$.

Stresory w pracy. Stresory w pracy mierzyliśmy za pomocą trzech skal: 1. Skali Ograniczeń Organizacyjnych (Organizational Contraints Scale), która składa się z 11 stwierdzeń (np. „Jak często jest Ci trudno lub wydaje Ci się niemożliwe, żeby wykonać swoją prace z powodu sprzecznych wymagań w pracy”), 2. Skali Konfliktu Interpersonalnego (Interpersonal Conflicts at Work), która składa się z 4 stwierdzeń (np. „Jak często ludzie w pracy krzyczą na Ciebie?”) i 3. Skali Obciążenia Pracą (Quantitative Workload Inventory), składającą się z 5 stwierdzeń (np.: „Jak często Twoja praca wymaga szybkiego działania?”) autorstwa Spectora i Jexa (1998) w polskiej adaptacji Baki i Bazińskiej (2016). Wszystkie skale mają pięciostopniową skalę odpowiedzi (od 1 = mniej niż w miesiącu lub nigdy, do 5 = kilka razy w tygodniu). Skale te były wcześniej wykorzystane w badaniach polskich nauczycieli (Baka, Cieślak, 2010). Współczynniki rzetelności dla skal były bardzo dobre (odpowiednio: $\alpha=0,87 ; \alpha=0,81$ i $\alpha=0,80$ ).

Kultura szkoły. Do pomiaru kultury szkoły zastosowaliśmy kwestionariusz School Culture Survey-Teacher Form (SCS-TF) Gruenerta (1998) w polskiej adaptacji Tłuściak-Deliowskiej i Dernowskiej (2018). Kwestionariusz składa się z 35 itemów z pięciostopniową skalą odpowiedzi (od 1 = zdecydowanie się nie zgadzam, do 5 = zdecydowanie się zgadzam). W tym ujęciu na kulturę szkoły składa się 6 wymiarów: wspólne przywództwo (np. „Dyrekcja docenia pomysły i propozycje nauczycieli”), współpraca nauczycieli (np. „Nauczyciele poświęcają znaczną ilość czasu na wspólne planowanie pracy dydaktyczno-wychowawczej”), rozwój zawodowy (np. „Rozwój zawodowy jest doceniany przez dyrekcję szkoły”), wzajemne wsparcie (np. „Nauczyciele darzą się wzajemnym zaufaniem”), jedność celu (np. „Nauczyciele wspierają misję szkoły) oraz partnerstwo na rzecz uczenia się (np. „Rodzice mają zaufanie do profesjonalnych osądów formułowanych przez nauczycieli”).

\subsection{Procedura}

Badanie przeprowadzono audytoryjnie na zajęciach dla studentów studiów magisterskich (specjalność: pedagogika wczesnoszkolna, pedagogika korekcyjna, edukacja i rehabilitacja osób z niepełnosprawnością intelektualną) oraz na zajęciach słuchaczy studiów podyplomowych (oligofrenopedagogika) w okresie od marca do maja 2017roku. Badanie miało charakter dobrowolny i anonimowy. 


\section{WYNIKI}

Rezultaty analizowaliśmy w kilku krokach. W pierwszym z nich oszacowaliśmy podstawowe statystyki opisowe i korelacje pomiędzy wszystkimi zmiennymi wykorzystanymi w badaniu. Jak pokazuje tabela 1, zdecydowana większość korelacji była

Tabela 1. Statystyki opisowe i korelacje pomiędzy zmiennymi mierzonymi w badaniu

\begin{tabular}{|c|c|c|c|c|c|c|c|c|c|c|c|c|c|}
\hline & $\mathbf{M}$ & SD & 1 & 3 & 4 & 5 & 6 & 7 & 8 & 9 & 10 & 11 & 12 \\
\hline $\begin{array}{l}\text { 1: Konflikt } \\
\text { interperso- } \\
\text { nalny }\end{array}$ & 1,28 & 0,46 & 0,49 & 0,17 & 0,78 & $-0,21$ & $-0,21$ & $-0,14$ & $-0,26$ & $-0,21$ & $-0,13$ & $-0,20$ & $-0,26$ \\
\hline $\begin{array}{l}\text { 2: Ogra- } \\
\text { niczenia } \\
\text { organiza- } \\
\text { cyjne }\end{array}$ & 2,04 & 0,74 & & 0,29 & 0,84 & $-0,41$ & $-0,34$ & $-0,34$ & $-0,36$ & $-0,36$ & $-0,26$ & $-0,36$ & $-0,25$ \\
\hline $\begin{array}{l}\text { 3: Obcią- } \\
\text { żenie pracą }\end{array}$ & 3,64 & 0,84 & & 1 & 0,58 & $-0,12$ & $-0,07$ & 0,03 & $-0,13$ & $-0,10$ & $-0,02$ & $-0,07$ & 0,03 \\
\hline $\begin{array}{l}\text { 4: Stresory } \\
\text { (ogółem) }\end{array}$ & 0 & 1 & & & 1 & $-0,36$ & $-0,30$ & $-0,23$ & $-0,35$ & $-0,32$ & $-0,20$ & $-0,30$ & $-0,22$ \\
\hline $\begin{array}{l}\text { 5: Wspól- } \\
\text { ne przy- } \\
\text { wództwo }\end{array}$ & 3,40 & 0,79 & & & & 1 & 078, & 0,76 & 0,66 & 0,72 & 0,58 & 0,87 & 0,32 \\
\hline $\begin{array}{l}\text { 6: Współ- } \\
\text { praca } \\
\text { nauczycieli }\end{array}$ & 3,49 & 0,71 & & & & & 1 & 0,76 & 0,79 & 0,75 & 0,66 & 0,92 & 0,31 \\
\hline $\begin{array}{l}\text { 7: Rozwój } \\
\text { zawodowy }\end{array}$ & 3,76 & 0,72 & & & & & & 1 & 0,66 & 0,69 & 0,59 & 0,86 & 0,34 \\
\hline $\begin{array}{l}\text { 8: Wza- } \\
\text { jemne } \\
\text { wsparcie }\end{array}$ & 3,59 & 0,82 & & & & & & & 1 & 0,74 & 0,69 & 0,88 & 0,33 \\
\hline $\begin{array}{l}\text { 9: Jedność } \\
\text { celu }\end{array}$ & 3,60 & 0,76 & & & & & & & & 1 & 0,63 & 0,87 & 0,37 \\
\hline $\begin{array}{l}\text { 10: Part- } \\
\text { nerstwo } \\
\text { na rzecz } \\
\text { uczenia się }\end{array}$ & 3,44 & 0,73 & & & & & & & & & 1 & 0,79 & 0,25 \\
\hline $\begin{array}{l}\text { 11: Kultura } \\
\text { (ogółem) }\end{array}$ & 0 & 1 & & & & & & & & & & 1 & 0,30 \\
\hline $\begin{array}{l}\text { 12: Zaan- } \\
\text { gażowanie } \\
\text { w pracę }\end{array}$ & 4,43 & 0,98 & & & & & & & & & & & 1 \\
\hline
\end{tabular}

Uwaga: $\mathrm{N}=449$. Podane współczynniki korelacji są istotne statystycznie na poziomie $\mathrm{p}<0,01$, jeśli ich wartość bezwzględna jest równa lub większa niż $r=|0,14|$, a na poziomie $\mathrm{p}<0,05$, jeśli przewyższa $\mathrm{r}=|0,12|$.

Źródło: Badanie własne. 
istotna statystycznie i miała oczekiwany kierunek. W szczególności nauczycielskie zaangażowanie w pracę było negatywnie związane z odczuwanym konfliktem interpersonalnym ze współpracownikami $(r=-0,26)$ i postrzeganymi ograniczeniami organizacyjnymi ( $r=-0,25$, w obu przypadkach $\mathrm{p}<0,001)$. Co zaskakujące, zaangażowanie było niezależne od obciążenia pracą $(r=0,03, p=0,48)$. Pozytywna ocena kultury szkoły dodatnio wiązała się z zaangażowaniem nauczycieli (r pomiędzy 0,25 a 0,37, w zależności od wymiaru kultury szkoły, wszystkie $p<0,001$ ), zaś związki pomiędzy stresorami w pracy a oceną kultury szkoły, co do zasady były negatywne i w zdecydowanej większości statystycznie istotne (zob. tabela 1).

W drugim kroku zbudowaliśmy dwa niezależne modele regresji wielokrotnej (zob. tabela 2). W modelu pierwszym predyktorami zaangażowania nauczycieli były szczegółowe składowe wymiarów powodujących stres oraz charakterystyki

Tabela 2. Stresory w pracy i kultura szkoły jako wymiary przewidujące zaangażowanie nauczycieli w pracę - rezultaty analiz regresji

\begin{tabular}{lllll}
\hline & Model 1 & & Model 2 & \\
\cline { 2 - 5 } & $\mathbf{B}$ & $\mathbf{p}$ & $\mathbf{B}$ & $\mathbf{p}$ \\
\hline Konflikt interpersonalny & $-0,16$ & 0,005 & --- & --- \\
\hline Ograniczenia organizacyjne & $-0,05$ & 0,42 & --- & --- \\
\hline Obciążenie pracą & 0,08 & 0,13 & --- & --- \\
\hline Stresory w pracy (ogółem) & --- & --- & $-0,15$ & 0,002 \\
\hline & & & & \\
\hline Wspólne przywództwo & 0,01 & 0,91 & --- & --- \\
\hline Współpraca nauczycieli ${ }^{\text {a }}$ & 0,24 & $<0,001$ & --- & --- \\
\hline Rozwój zawodowy & 0,12 & 0,14 & --- & --- \\
\hline Jedność celu & 0,22 & 0,008 & --- & --- \\
\hline Wzajemne wsparcie & 0,04 & 0,64 & --- & --- \\
\hline Partnerstwo na rzecz uczenia się & $-0,03$ & 0,69 & --- & --- \\
\hline Kultura (ogółem) & --- & --- & 0,25 & $<0,001$ \\
\hline R2 & 0,17 & & 0,10 & \\
\hline
\end{tabular}

Uwaga: Model 1 - szczegółowe składowe czynników powodujących stres oraz wymiarów kultury szkoły wprowadzone jako predyktory zaangażowania. Model 2 - zagregowany czynnik stresu (rezultat analizy głównych składowych) oraz kultury szkoły (rezultat analizy głównych składowych) wprowadzone jako predyktory.

a: ze względu na wysoką współliniowość z pozostałymi wymiarami kultury szkoły (współczynnik VIF>4) czynnik współpracy nauczycieli został wprowadzony do modelu osobno wraz z stresorami w pracy.

Źródło: Badanie własne. 
kultury szkoły. Ponieważ w jednym przypadku (skala „współpraca nauczycieli”) mieliśmy do czynienia z dość silną współliniowością (współczynnik VIF>4), model ten stworzyliśmy z wyłączeniem tego predyktora, zaś znaczenie współpracy nauczycieli dla ich zaangażowania w pracę oszacowaliśmy w osobnym modelu regresji. Model 2 był w swoich założeniach bardziej ogólny - zaangażowanie nauczycieli wyjaśnialiśmy w nim bowiem ogólnym nasileniem stresorów w pracy (zagregowaną zmienną uzyskaną w toku analizy głównych składowych) oraz podobnie zagregowaną - kulturą szkoły.

Jak ilustrują to współczynniki zawarte w tabeli 2, model 1 wyjaśniał 17\% zmienności nauczycielskiego zaangażowania. Okazało się, że zaangażowanie nauczycieli malało przy wzroście postrzeganych konfliktów interpersonalnych w szkole $(ß=-0,16, p=0,005)$, jednak dwie pozostałe grupy stresorów (ograniczenia organizacyjne i obciążenie pracą) nie obniżały istotnie zaangażowania. Pośród testowanych 6 składowych kultury szkoły statystycznie istotne i pozytywne efekty odnotowaliśmy przy współpracy nauczycieli $(\Re=0,24, \mathrm{p}<0,001)$ oraz postrzeganej jedności celu $(ß=0,22, \mathrm{p}<0,001)$.

Model 2, posługując się zagregowanymi miarami stresorów i kultury szkoły, był w stanie wyjaśnić jedynie 10\% zmienności zaangażowania nauczycieli. Zgodnie z oczekiwaniami, nasilenie stresu przekładało się negatywnie na zaangażowanie nauczycieli ( $(=-0,15, p=0,002)$, podczas gdy percepcja kultury szkoły jako wspierającej była istotnym i pozytywnym predyktorem nauczycielskiego zaangażowania $(ß=0,25, \mathrm{p}<0,001)$.

Przypomnijmy, że kluczowa hipoteza naszego studium zakładała istnienie efektu buforującego - a więc mechanizmu moderacji, zgodnie z którym sprzyjająca kultura środowiska pracy modyfikuje relacje pomiędzy stresorami a zaangażowaniem nauczycieli. W związku z faktem, że negatywne efekty stresu odnotowaliśmy w przypadku konfliktu interpersonalnego i czynnika ogólnego, te właśnie wymiary uczyniliśmy predyktorami w analizie moderacji. Moderatorami były postrzegana jedność celu (w przypadku konfliktu interpersonalnego) i uogólniona kultura szkoły (przy ogólnym czynniku stresu) ${ }^{7}$. Rezultaty modeli regresyjnych testujących efekty moderacyjne zawiera tabela 3.

7 Wcześniejszy model pokazał również pozytywne oddziaływanie współpracy między nauczycielami na ich zaangażowanie w pracę. Zrezygnowaliśmy jednak z włączania współpracy między nauczycielami jako potencjalnego moderatora, ze względu na ryzyko tautologiczności analizowanej relacji - trudno bowiem argumentować, że współpraca pomiędzy nauczycielami zmienia charakter związku pomiędzy konfliktem interpersonalnym a zaangażowaniem - to zaś ze względu na opozycyjny charakter konfliktu interpersonalnego i współpracy między nauczycielami. Można by wręcz argumentować, że w tym konkretnym przypadku to wymiar konfliktu interpersonalnego 
Tabela 3. Testowanie mechanizmu buforowego kultury szkoły w relacji czynników powodujących stres i zaangażowania nauczycieli - rezultaty analiz moderacji.

\begin{tabular}{lllll}
\hline & Model 1 & \multicolumn{3}{l}{ Model 2 } \\
\cline { 2 - 5 } & $\mathbf{B}$ & $\mathbf{p}$ & $\mathbf{B}$ & $\mathbf{p}$ \\
\hline Konflikt interpersonalny $(K I)$ & $-0,15$ & 0,10 & --- & --- \\
\hline Jedność celu $(J C)$ & 0,28 & $<0,001$ & --- & --- \\
\hline Efekt interakcyjny $K I$ $x$ JC & 0,41 & $<0,001$ & --- & --- \\
\hline Stres ogólnie $(S)$ & --- & --- & $-0,14$ & 0,002 \\
\hline Kultura ogółem $(K)$ & --- & --- & 0,22 & $<0,001$ \\
\hline Efekt interakcyjny $S \times K$ & & & 0,07 & 0,052 \\
\hline R2 & 0,24 & & 0,11 & \\
\hline R2 interakcji & 0,07 & & 0,01 & \\
\hline
\end{tabular}

Źródło: Badanie własne.

Oczekiwane efekty interakcyjne okazały się statystycznie istotne i pozytywne, choć w przypadku wskaźników zagregowanych oszacowany efekt interakcyjny był istotny na granicy istotności statystycznej $(\mathrm{p}=0,052)$. Dekompozycja efektów zilustrowana na rysunku 1 wskazuje na istnienie relacji zakładanej w hipotezie 2. W przypadku związku pomiędzy konfliktem interpersonalnym i zaangażowaniem w pracę, moderowanej przez podzielaną jedność celu, negatywny efekt konfliktu interpersonalnego był widoczny jedynie wśród tych nauczycieli, którzy nie podzielali wspólnych celów ze swoimi kolegami (wyniki poniżej 1 odchylenia standardowego na skali jedności celów: $ß=-0,60, \mathrm{p}<0,001)$. Negatywny efekt konfliktu interpersonalnego przestawał być istotny, gdy jedność celów była umiarkowana ( $-0,15, p=0,10)$, zaś konflikt zaczynał wręcz nieznacznie sprzyjać zaangażowaniu, gdy jedność celu była wysoka, a więc ewentualne spory mogły służyć realizacji celów ( $=0,26, \mathrm{p}=0,067)$.

Moderacyjny model 2 (zob. również: prawa strona rysunku 1) pokazał, że negatywne oddziaływanie stresorów na zaangażowanie nauczycieli dawało się zauważyć jedynie w tych placówkach, gdzie kultura szkoły oceniona została jako

pośredniczy (mediuje) związek pomiędzy nauczycielską współpracą a zaangażowaniem w pracę. $\mathrm{W}$ istocie, pominięta w tym miejscu analiza mediacji czyni takie rozumowanie prawdopodobnym oszacowany efekt pośredni: współpraca $\rightarrow$ konflikt $\rightarrow$ zaangażowanie okazał się statystycznie istotny ( $(=0,03, p=0,008)$. Współpraca negatywnie przewidywała ryzyko konfliktów $(ß=-0,10, p<0,001)$, zaś intensywność konfliktów była negatywnym predyktorem zaangażowania $(\Omega=-0,34, p<0,001)$. Efekt całkowity współpracy na zaangażowanie był statystycznie istotny $(\Omega=0,27, \mathrm{p}<0,001)$, podobnie jak efekt bezpośredni $(\S=0,24, \mathrm{p}<0,001)$. 

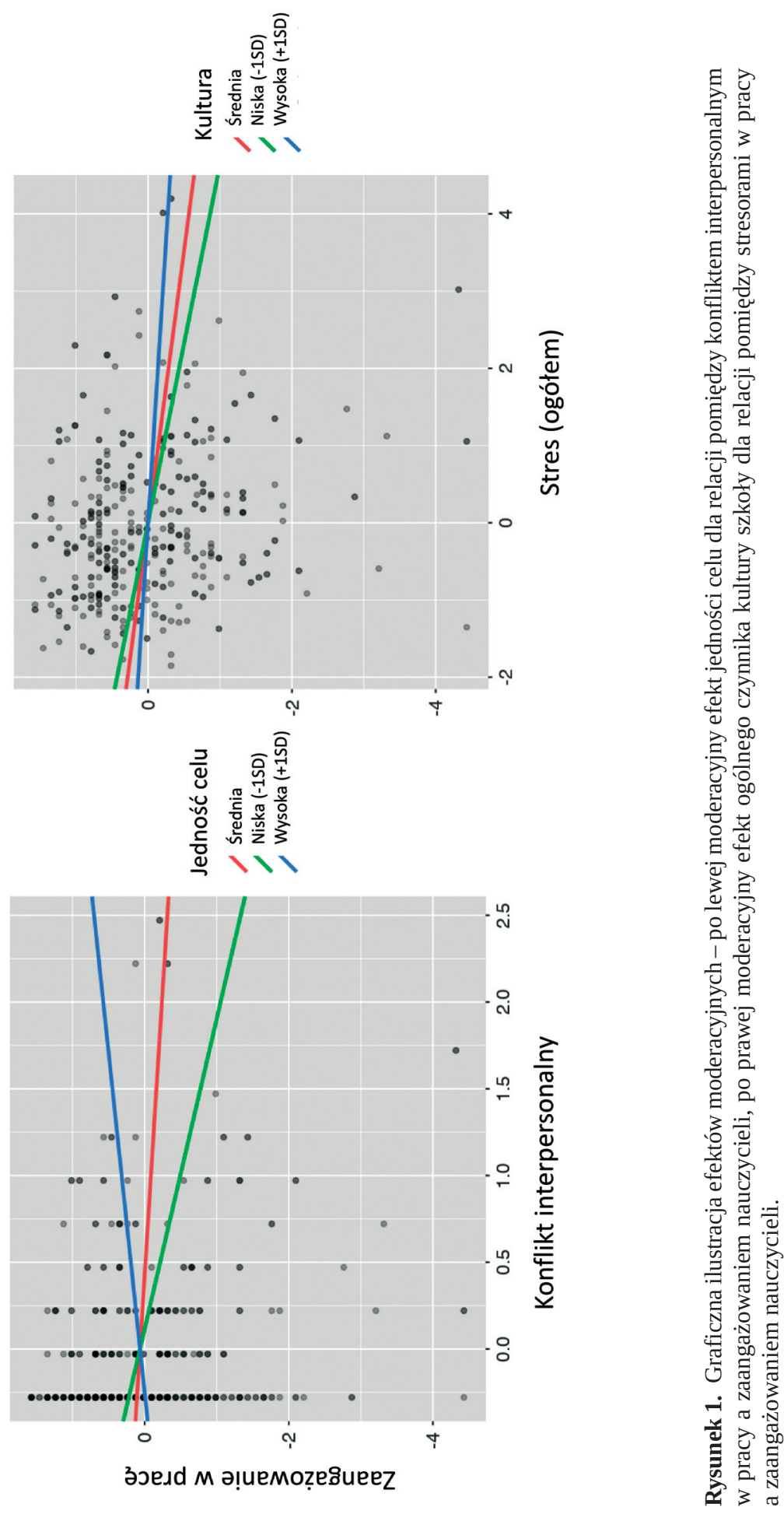
mało (-1 odchylenie standardowe poniżej średniej) lub umiarkowanie wspierająca: odpowiednio $ß=-0,22, p<0,001$ i $ß=-0,14, p=0,001$. Efekt ten znikał $w$ tych szkołach, które charakteryzowały się natomiast kulturą dostarczającą istotnego wsparcia (efekt o jedno odchylenie standardowe powyżej średniej $-\S=-0,07$, $\mathrm{p}=0,26)$.

\section{DYSKUSJA}

W prezentowanych badaniach nie tylko chcieliśmy dokonać replikacji poniekąd oczywistego ustalenia, że stresory w pracy negatywnie przekładają się na nauczycielskie zaangażowanie w pracę, ale również przetestować hipotezę o moderującej roli kultury szkoły w relacji między stresorami a zaangażowaniem w pracę. Uzyskane wyniki w znacznej mierze potwierdziły nasze hipotezy i uprawdopodobniają twierdzenie, że kultura szkoły niweluje negatywne relacje pomiędzy nasileniem czynników stresogennych w pracy a zaangażowaniem nauczycieli.

Zgodnie z oczekiwaniami, odnotowaliśmy istotną statystycznie, ujemną relację pomiędzy intensywnością konfliktów interpersonalnych w szkole a zaangażowaniem w pracę nauczycieli. Choć wynik ten trudno uznać za zaskakujący, to podkreślić należy, że dobrze współgra on z rezultatami wcześniejszych studiów (zob. np.: Bakker i in., 2003; Demerouti i in., 2001). Jeśli wziąć pod uwagę, że w realiach organizacyjnych konflikty interpersonalne rzadko mają charakter chłodnych sporów wokół istoty dyskutowanych spraw, częściej natomiast przeradzają się w spory o charakterze osobistym, trudno oczekiwać, żeby taki rodzaj konfliktów sprzyjał chęci angażowania się nauczycieli w działania organizacyjne.

Zastanawia fakt, dlaczego nie odnotowaliśmy podobnych relacji w odniesieniu do związków pomiędzy obciążeniem pracą a ograniczeniami organizacyjnymi przypomnijmy, że te akurat wymiary nie wiązały się istotnie z nauczycielskim zaangażowaniem. Trudno spekulować nad powodami, które mogłyby stać za zaobserwowanym brakiem związku (w istocie mamy tu bowiem do czynienia z hipotezą zerową). Ograniczenia organizacyjne obejmują szereg różnych czynników, które wiążą się z jednej strony z ograniczeniami interpersonalnymi - zachowaniami przełożonego i innych pracowników, a z drugiej z ograniczeniami związanymi z samą pracą (np. niedoborem wyposażenia i zasobów, sprzecznymi wymaganiami w pracy, niewystarczającą wiedzą do wykonania określonego zadania, niedostatecznej pomocy od innych pracowników). Niewykluczone więc, że 
złożoność samej tej kategorii sprawia, że możemy mieć do czynienia z różnorodnymi relacjami (być może nawet o przeciwstawnych kierunkach), które być może wzajemne się znoszą. W istocie, jedno z badań pokazało inny mechanizm działania zaangażowania w stosunku do różnych stresorów: o ile bowiem wysoki poziom konfliktów interpersonalnych i ograniczeń organizacyjnych prowadził do niskiego zaangażowania, o tyle wysoki poziom obciążenia pracą był wyznacznikiem silnego zaangażowania (Derbis, Baka, 2011).

Dyskutując o uzyskanych wynikach warto odwołać się do rezultatów metaanaliz, które pozwoliły na wyodrębnienie dwóch rodzajów wymagań w pracy. Pierwsze to wymagania określone jako wyzwania (challenges), jakie w percepcji pracowników mają potencjał do promowania mistrzostwa, rozwoju osobistego i przyszłych zysków (np.: obciążenie pracą, presja czasu, odpowiedzialność, różnorodność zadań na stanowisku pracy). Drugie wymagania to ograniczenia (hindrances), które uniemożliwiają rozwój osobisty, uczenie się i osiągnięcie celu (np.: konflikt roli, niejasność roli, ograniczenia organizacyjne, biurokracja) (Crawford, LePine, Rich, 2010, s. 52). Relacje między wymaganiami a zaangażowaniem zmieniają się w zależności od rodzaju wymagań: o ile ograniczenia (hindrances) są ujemnie powiązane z zaangażowaniem w pracę, wyzwania wiążą się z nim pozytywnie (Bakker, Demerouti, 2014). Zgodnie z modelem JD-R zasoby pracy ujemnie wiązały się z wypaleniem, a pozytywnie - z zaangażowaniem. Wspominana metaanaliza potwierdza więc, że wymagania w pracy mogą różnie wiązać się z zaangażowaniem, w zależności od specyficznego charakteru analizowanych wymiarów wymagań (Crawford i in., s. 52).

Kluczowa dla naszego studium hipoteza druga zakładała, że kultura szkoły będzie buforowała negatywny efekt stresorów w pracy na zaangażowanie w pracę. Oczekiwany efekt interakcyjny znalazł swoje potwierdzenie.

Kultura szkoły jest nierozerwalnie związana z misją i wizją szkoły jako środowiska pracy, w którym nauczyciele działają zgodnie z nią (por. Fisher i in., 2012). Misja odzwierciedla priorytety szkoły i nadaje wyraźny kierunek działaniom nauczycieli w ich codziennych kontaktach z uczniami i innymi podmiotami edukacji. Nauczyciele znający, rozumiejący i wspierający misję szkoły świadomie budują właściwe środowisko kształcenia dla rozwoju uczniów. Podzielana wizja i misja organizacji przez większość członków grona pedagogicznego sprzyja osiąganiu pożądanych efektów kształcenia. Uwzględniona w naszych analizach „jedność celu” okazała się szczególnie ważna dla zaangażowania, umożliwia bowiem realizację wspólnej wizji i priorytetów organizacji, jaką jest szkoła. Trudno realizować zadania i pomysły, gdy pracownicy - w naszym przypadku nauczyciele - „nie podążają” w stronę wspólnych priorytetów szkoły i nie podzielają podstawowych 
założeń dotyczących jej funkcjonowania. Nawet dobre pomysły nie mogą być zrealizowane, gdy są produktem rzeczywistości, która jest „pokawałkowana”, fragmentaryczna (por. Mazurkiewicz, 2011), przede wszystkim jednak - która nie jest powszechnie podzielana.

Drugi oczekiwany efekt interakcyjny uogólnionej kultury szkoły na relację między zagregowanym wskaźnikiem stresorów w pracy i zaangażowaniem w pracę, okazał się mniej spektakularny. Rezultat ten pozostaje jednak w zgodzie z modelem JD-R, który wskazuje na rolę wielu różnych zasobów pracy, które mogą buforować wpływ wymagań w pracy na zaangażowanie pracowników (Bakker i in., 2007).

Wspierająca kultura szkoły oznacza możliwość uczestnictwa nauczycieli w przywództwie szkolnym. Jej istotą jest wspólne tworzenie uwspólnionej edukacyjnej wizji szkoły, w której nauczyciele współpracują ze sobą, wzajemnie obserwują swoją pracę dydaktyczną i otwarcie dyskutują o praktyce nauczania. Misja i wizja szkoły jest popierana i rewidowana przez wszystkich uczestników procesu edukacji (por. Fisher i in., 2012). Nauczyciele nieustanie rozwijają swoje kompetencje i umiejętności dydaktyczne, co przekłada się na rozwój uczniów i doskonalenie jakości pracy szkoły. Wzajemne wsparcie i pomoc w różnych problemach/zadaniach ze strony innych nauczycieli daje poczucie bezpieczeństwa i komfortu psychicznego w szkole. Rdzeń wspierającej kultury szkoły stanowią więc relacje sprzyjające współpracy i zaangażowaniu nauczycieli, uczniów, rodziców na rzecz uczenia się i oczekiwanych osiągnięć szkolnych uczniów.

Wyniki naszych badań należy analizować w kontekście ich naturalnych ograniczeń. Pierwszym z nich jest korelacyjny charakter naszego studium i jego silne oparcie na metodach samoopisowych. Nie bez znaczenia jest też zdecydowana dominacja kobiet w naszej próbie. Choć feminizacja profesji nauczycielskiej jest faktem, to w naszym badaniu mamy jednak do czynienia z wyraźnym „skrzywieniem” rozkładu płci w stosunku do danych systemowych. Wreszcie, ograniczeniem jest celowy dobór próby, mocno ograniczający jakiekolwiek wnioskowanie na populację nauczycieli.

Konkludując, niezależnie od wspomnianych ograniczeń, nasze badanie pokazuje, że kultura szkoły ma unikalny, bo moderujący wpływ na relację pomiędzy czynnikami stresogennymi a zaangażowaniem nauczycieli w pracę. Biorąc pod uwagę jak wiele różnych stresorów obecnych jest w codziennej pracy nauczyciela, ustalenie to może przyczynić się do tworzenia programów takiego wzmacniania kultury szkoły, aby móc z powodzeniem stymulować zaangażowanie nauczycieli. 


\section{Bibliografia}

Adrjan, B. (2001). Kultura szkoły. W poszukiwaniu nieuchwytnego. Kraków: Oficyna Wydawnicza Impuls.

Ashforth, B.E. (1985). Climate formations: issues and extensions. Academy of Management Review, 10(4), s. 837-847.

Baka, Ł. (2013). Wymagania i zasoby w pracy a wypalenie zawodowe i zaangażowanie w pracy nauczycieli. Częstochowa: AJD.

Baka, Ł., Bazińska, R. (2016). Polish adaptation of three self-report measures of job stressors: the Interpersonal Conflict at Work Scale, the Quantitative Workload Inventory and the Organizational Constraints Scale. International Journal of Occupational Safety and Ergonomics, 22(1), s. 32-39.

Baka, Ł., Cieślak, R. (2010). Zależności między stresorami w pracy a wypaleniem zawodowym i zaangażowaniem w pracę w grupie nauczycieli: pośrednicząca rola przekonań o własnej skuteczności i wsparcia społecznego. Studia Psychologiczne, 48(3), s. 5-18.

Bakker, A.B., Demerouti, E. (2014). Job demands-resources theory. W: P.Y. Chen, C.L. Cooper (red.), Work and Wellbeing: Wellbeing: A complete reference guide, III (s. 37-64). Chichester, UK: Wiley-Blackwell.

Bakker, A.B., Schaufeli, W.B. i in. (2008). Work engagement: An emerging concept in occupational health psychology. Work \& Stress, 22(3), s. 187-200.

Bakker, A.B. (2011). An evidence-based model of work engagement. Current Directions in Psychological Science, 20, s. 265-269.

Bakker, A.B., Demerouti, E. (2007). The Job Demands-Resources model: state of the art. Journal of Managerial Psychology, 22(3), s. 309-328.

Bakker, A.B., Demerouti, E., Schaufeli, W.B. (2003). Dual processes at working a call centre: An application of the job demands-resources model. European Journal of Work and Organizational Psychology, 12, s. 393-417.

Bakker, A.B., Demerouti, E. i in. (2003). A multi-group analysis of the Job Demands-Resources model in four home care organizations. International Journal of Stress Management, 10, s. 16-38.

Bakker, A.B., Hakanen, J., Demerouti, E., Xanthopolou, D. (2007). Job resources boost work engagement, particularly when job demands are high. Journal of Educational Psychology, 99, s. 274-284.

Balay, R., Ipek, C. (2010). Teachers' Perception of Organizational Culture and Organizational Commitment in Turkish Primary Schools. Zeitschrift fur die Welt der Turken, 2(1), s. 363-384.

Beer, J., Beer, J. (1992). Burnout and stress, depression and self-esteem of teachers. Psychological Reports, 71, s. 1331-1336.

Betoret, F.D. (2006). Stressors, self-efficacy, coping resources, and burnout among secondary school teachers in Spain. Educational Psychology, 26, s. 519-539.

Bruner, D.Y., Greenlee, B.J. (2003). Analysis of School Work Culture in Schools That Implement Comprehensive School Reform Models. Journal of Research for Educational Leaders, 2(3), s. 33-53.

Chirkowska-Smolak, T. (2012). Psychologiczny model zaangażowania w pracę. Poznań: Wydawnictwo Naukowe UAM. 
Cohen, S., Wills, T.A. (1985). Stress, social suport and the buffering hypothesis. Psychological Bulletin, 98, s. 310-357.

Collie, R.J., Shapka, J.D., Perry, N.E. (2011). Predicting Teacher Commitment: The Impact of School Climate and Social-Emotional Learning. Psychology in Schools, 48(10), s. $1034-1048$

Deal, T.E., Kennedy, A.A. (1982). Corporate cultures: The rights and rituals of corporate life. Reading, MA: Addison-Wesley.

Demerouti, E., Bakker, A.B. i in. (2001). The job demands-resources model of burnout. Journal of Applied Psychology, 86, s. 499-512.

Denison, D. (1996). What is the difference between organizational culture and organizational climate? A native's point of view on a decade of paradigm wars. Academy of Management Review, 12, s. 619-654.

Derbis, R., Baka, Ł. (2011). Znaczenie wsparcia społecznego i zaangażowania w pracę dla związku stresorów w pracy i wypalenia zawodowego. Czasopismo Psychologiczne, 17(2), s. 277-287.

Dernowska, U., Tłuściak-Deliowska, A. (2015). Kultura szkoły. Studium teoretyczno-empiryczne. Kraków: Oficyna Wydawnicza Impuls.

Ekvall, G. (1996). Organizational climate for creativity and innovation. European Journal of Work and Organizational Psychology, 5, s. 105-123.

Fisher, D., Frey, N., Pumpian, I. (2012). How to create a culture of achievement in your school and classroom. Alexandria: ASCD.

Forehand, G.A., Von Haller, G. (1964). Environmental variation in studies of organizational behavior. Psychological Bulletin, 62(6), s. 361-382.

Frese, M. (1999). Social support as moderator of the relationship between work stressors and psychological dysfunctioning: A longitudinal study with objective measures. Journal of Occupational Health Psychology, 4, s. 179-192.

Glick, W.H. (1985). Conceptualizing and Measuring Organizational and Psychological Climate: Pitfalls in Multilevel Research. The Academy of Management Review, 10(3), s. 601-616.

Gruenert, S. (1998). Development of a school cultural survey. Unpublished doctoral dissertation. Columbia: University of Missouri.

Gumuseli, A.I., Eryilmaz, A. (2011). The measurment of collaborative school culture (CSC) on Turkish Schools. New Horizons in Education, 59(2), s. 13-26.

Hakanen, J., Bakker, A.B., Schaufeli, W.B. (2006). Burnout and work engagement among teachers. Journal of School Psychology, 43, s. 495-513.

Hall, G.B., Dollard, M.F. i in. (2013). Psychosocial safety climate buffers effects of job demands on depression and positive organizational behaviors. Anxiety, Stres and Coping, 26(4), s. 355-377

Hargreaves, A. (1994). Changing teachers, changing times: teachers' work and culture in the post-modern age. New York: Teachers College Press.

Heck, R.H., Marcoulides, G.A. (1996). School culture and performance: Testing the invariance of an organizational model. School Effectiveness and School Improvement, 7, s. 76-95.

Hofstede, G. (2000). Kultury i organizacje. Warszawa: Wydawnictwo Ekonomiczne. 
Hunter, S.T., Bedell, K.E., Mumford, M.D. (2007). Climate for creativity: A quantitative review. Creativity Research Journal, 19, s. 69-90.

James, L.R., Jones, A.P. (1974). Organizational climate: A review of theory and research. Psychological Bulletin, 81(12), s. 1096-1112.

Karwowski, M. (2009). Klimat dla kreatywności: koncepcje, metody, badania. Warszawa: Centrum Doradztwa i Informacji Difin.

Karwowski, M. (2013). „Pogoda dla wysokiej jakości kształcenia”. Jak klimat klasy i szkoły wiąże się ze wskaźnikami edukacyjnej wartości dodanej? W: M. Karwowski (red.), Ścieżki rozwoju edukacyjnego młodzieży - szkoły pogimnazjalne (s. 161-184). Warszawa: IFiS.

King, E.B., Chermont, K. i in. (2007). How innovation can alleviate negative consequences of demanding work contexts: The influence of climate for innovation on organizational outcomes. Journal of Occupational and Organizational Psychology, 80, s. 631-645.

Kokkinos, C.M. (2007). Job stressors, personality and burnout in primary school teachers. British Journal of Educational Psychology, 77, s. 229-243.

Kulesza, M. (2011). Klimat szkoły a zachowania agresywne i przemocowe uczniów. Łódź: Wydawnictwo Uniwersytetu Łódzkiego.

Langelaan, S., Bakker, A.B. i in. (2006). Burnout and work engagement: do individual differences make a difference? Personality and Individual Differences, 40, s. 521-532.

Lawler, E.E., Hall, D.T. (1970). Relationship of job characteristics to job involvement, satisfaction, and intrinsic motivation. Journal of Applied Psychology, 54(4), s. 305-312.

Lebuda, I. (2014). Kształtowanie poczucia sukcesu nauczycieli. Kraków: Nomos.

Leiter, M.P., Maslach, C. (1999). Six areas of worklife. A model of the organizational context of burnout. Journal of Health and Human Resources Administration, 21, s. 472-489.

Łaguna, M., Mielniczuk, E. i in. (2015). Przywiązanie do organizacji i zaangażowanie w pracę - koncepcje teoretyczne i problemy terminologiczne. Medycyna Pracy, 66(2), s. 277-284.

MacNeil, A.J., Prater, D.J., Busch, S. (2009). The effects of school culture and climate on student achievement. International Journal of Leadership in Education, 12, s. 73-84.

Maslowski, R. (2001). School Culture and School Performance. An explorative study into the Organizational Culture of Secondary Schools and their effects. Ph.D. thesis. University of Twente.

Mazurkiewicz, G. (2011). Przywództwo edukacyjne. Odpowiedzialne zarządzanie edukacją wobec wyzwań współczesności. Kraków: Wydawnictwo Uniwersytetu Jagielońskiego.

Mearne, J., Cain, J.E. (2003). Relationship between teachers' occupational stress and their burnout and distress: roles of coping and negative mood regulation expectancies. Anxiety, Stress and Coping, 16, s. 71-82.

Meijman, T.F., Mulder, G. (1998). Psychological Aspects of Workload. W: Drenth, P.J.D., Thierry, H. (red.), Handbook of Work and Organizational Psychology (s. 5-33). Hove: Psychology Press.

Nalaskowski, A. (2002). Przestrzenie i miejsca szkoły. Kraków: Oficyna Wydawnicza Impuls.

Nielsen, M.B., Mearns, K. i in. (2011). Using the Job Demands-Resources model to investi- 
gate risk perception, safety climate and job satisfaction in safety critical organizations. Scandinavian Journal of Psychology, 52, s. 465-475.

O’Reilly, C.A., Chatman, J., Caldwell, D.F. (1991). People and organizational culture: a profil comparisons approach to assessing person-organization fit. Academy of Management Journal, 34, s. 487-516.

Olson, L. (2009). A study of school culture, leadership, teacher quality and student outcomes via a performance framework in elementary schools participating in a school reform initiative. PhD. dissertation. University of Florida.

Paluchowski, W.J. (1998). Klimat organizacyjny i jego pomiar. W: S. Witkowski, T. Listwan (red.). Psychologiczne wyznaczniki sukcesu w zarządzaniu, IV. Wrocław: Wydawnictwo Uniwersytetu Wrocławskiego.

Peterson, K.D., Deal, T.E. (2002). The shaping school culture fieldbook. San Francisco, CA: Jossey-Bass.

Polak, K. (2007). Kultura szkoły. Od relacji społecznych do języka uczniowskiego. Kraków: Wydawnictwo UJ.

Poraj, G. (2009). Od pasji do frustracji: modele psychologicznego funkcjonowania nauczycieli. Łódź: Wydawnictwo Uniwersytetu Łódzkiego.

Roulston, K., Legette, R., Womack, S.T. (2005). Beginning music teachers' perceptions of the transition from university to teaching in schools. Music Education Research, 7, s. 59-82.

Salanova, M. Bakker, A.B., Llorens, S. (2006). Flow at work: evidence for an upward spiral of personal and organizational resources. Journal of Happiness Studies, 7, s. 1-22.

Sargent, L.D., Terry, D.J. (2000). The moderoting role of social support in Karasek's job strain model. Work \& Stress, 14, s. 245-261.

Schaufeli, W.B., Bakker, A.B. (2004). Job demands, job resources and their relationships with burnout and engagement: a multi-sample study. Journal of Organizational Behaviour, 25, s. 293-315.

Schaufeli, W.B., Salanova M. i in. (2002). The measurment of engagement and burnout: a two sample confirmatory factor analytic approach. Journal of Happiness Studies, 3, s. 71-92.

Schein, E.H. (2004). Organizational Culture and Leadership. 3rd ed. San Francisco: Jossey-Bass.

Schneider, B., Snyder, R.A. (1975). Some relationships between job satisfaction and organization climate. Journal of Applied Psychology, 60(3), s. 318-328.

Schoen, L.T., Teddlie, C. (2008). A new model of school culture: a response to a call for conceptual clarity. School Effectiveness and School Improvement, 19(2), s. 129-153.

Schonfeld, I.S. (1992). A longitudinal study of occupational stressors and depressive symptoms in first-year female teachers. Teaching and Teacher Education, 8, s. 151-158.

Silverthorne, C. (2004). The Impact of Organizational Culture and Person-Organization Fit on Organizational Commitment and Job Satisfaction in Taiwan. The Leadership \& Organization Development Journal, 25(7), s. 592-599.

Smoktunowicz, E., Cieślak, R., Żukowska, K. (2013). Rola wsparcia społecznego w kontekście stresu organizacyjnego oraz zaangażowania w pracę. Studia Psychologiczne, 51(4), s. 25-37. 
Spector, P.E., Jex, S.M. (1998). Development of four self-report measures of job stressors and strain: Interpersonal Conflict at Work Scale, Organizational Constraints Scale, Quantitative Workload Inventory and Physical Symptoms Inventory. Journal Occupational Health Psychology, 3(4), 356-367.

Strutyńska, E., Gralewski, J., Lebuda, I. (2016). Obciążenia zawodowe nauczycieli a klimat organizacyjny w szkołach ogólnodostępnych, integracyjnych i specjalnych. Studia z Teorii Wychowania, 7, s. 137-155.

Sułkowski, Ł. (2008). Czy warto zajmować się kulturą organizacyjną. Zarządzanie Zasobami Ludzkimi, 6, s. 9-25.

Surzykiewicz, J. (2000). Agresja i przemoc w szkole. Uwarunkowania socjoekologiczne. Warszawa: Centrum Metodyczne Pomocy Psychologiczno-Pedagogicznej.

Szabowska-Walaszczyk, A., Zawadzka, A.M., Wojtaś, M. (2011). Zaangażowanie w pracę i jego korelaty: adaptacja skali UWES autorstwa Schaufeliego i Bakkera. Psychologia Jakości Życia, 10(1), s. 57-74.

Terelak, J.F., Jankowska, P. (2009). Dostosowanie jednostka - organizacja a satysfakcja z pracy. Miscellanea Oeconomicae, 13(1), s. 229-254.

Tłuściak-Deliowska, A., Dernowska, U. (2016). Kultura współpracy w percepcji nauczycieli szkół gimnazjalnych. Studia Edukacyjne, 40, s. 127-148.

Tłuściak-Deliowska, A., Dernowska, U. (2018). Założenia teoretyczne i właściwości psychometryczne polskiej wersji kwestionariusza „Kultura szkoły” (School Culture Survey, SCS, S. Gruenert, J. Valentine, 1998). Warszawa: Wydawnictwo Akademii Pedagogiki Specjalnej.

Van der Doef, M., Maes, S. (1999). The job demand-control (-support) model and psychological well-being: a review of 20 years of empirical research. Work \& Stress, 13, s. $87-114$.

Van Houtte, M., Van Maele, D. (2011). The black box revelation: in search for conceptual clarity regarding climate and culture in school effectiveness research. Oxford Review of Education, 37(4), s. 505-524.

Wudarzewski, G. (2012). Wybrane koncepcje klimatu organizacyjnego. Zeszyty Naukowe Wyższej Szkoły Bankowej we Wrocławiu, 32, s. 221-242. 